\title{
Assessing the impact of land-cover changes on ecosystem services: A first step toward integrative planning in Bordeaux, France
}

\author{
Cabral Pedro ${ }^{1,5,{ }^{*}}$, Feger Clément ${ }^{2}$, Levrel Harold ${ }^{4,6}$, Chambolle Mélodie ${ }^{3}$, Basque Damien ${ }^{3}$
}

${ }_{1}^{1}$ NOVA IMS, Universidade Nova de Lisboa, 1070-312 Lisboa, Portugal

${ }^{2}$ Muséum National d'Histoire Naturelle, UMR 7204 - CESCO, Paris, France

${ }^{3}$ LyRE, Centre de Recherche de Suez Environnement (Lyonnaise des Eaux) Bordeaux, France

${ }_{5}^{4}$ CIRED, AgroParisTech, 45bis avenue de la Belle Gabrielle, 94736 Nogent-sur-Marne Cedex, France

${ }^{5}$ Université de Brest, UMR AMURE - Centre de droit et d'économie de la mer, IUEM, 12rue du Kergoat, CS 93837, 29238 Brest Cedex 3, France

${ }^{6}$ Ifremer, UMR M101, AMURE, Unité d'Economie Maritime, BP 70, F-29280 Plouzané Cedex, France

* Corresponding author : Pedro Cabral, email address : pcabral@novaims.unl.pt

\begin{abstract}
:
The quantification and integration of ecosystem services (ES) into urban planning decisions is becoming increasingly important. However, studies that quantify and analyze the impacts in terms of ES changes are still scarce. We analyzed multiple ES provided by the landscape of the Urban Community of Bordeaux (CUB), in France, between 1990 and 2006 as a result of land use and cover change (LUCC) with Corine Land Cover and other open data. These ES were selected with the help of local stakeholders and were calculated using a spatially explicit modeling approach with InVEST and own-produced models. It was found that all ES, except erosion regulation, have decreased as a consequence of LUCC. Results also suggest that LUCC change decisions which do not consider policy measures for ES protection tend to generate land use patterns providing lower levels of ES. This spatial explicit approach to ES modeling enables an informed discussion with stakeholders and may be used to effectively implement, monitor, and communicate future planning policies.
\end{abstract}

\section{Highlights}

- We use free tools and open data to study changes in ecosystem services (ES). We describe a strategy to include stakeholders in ES assessment. We provide relevant ES information for integrative urban planning. Land change decisions that ignore policy measures for ES tend to provide lower ES.

Keywords : Landscape services, Geographical information systems, Spatial planning, Land use and cover change, Corine land cover, Natural capital project 


\section{Introduction}

Ecosystem Services (ES) approaches are seen by many as a promising way to better take into account the ecosystems in the decision process because they seek to make visible the multiple contributions of nature to society and associated tradeoffs (Goldstein et al., 2012; Tallis and Kareiva, 2006). This is especially important for cities, as they accommodate an increasing number of the world's population, and depend on the ES beyond their boundaries to sustain long-term conditions for life, health, security, social relations and other aspects of human well-being (Gómez-Baggethun and Barton, 2013).

The production and use of information on the effects of LUCC management practices on ecosystem functioning is decisive for the design of policies able to ensure an effective provision of the desired ES (Nelson et al., 2009). However, this requires taking into account interactions between multiple human uses, which are a source of complexity for planning managers (Naeem et al., 2009). ES mapping tools and quantitative biophysical indicators that make ES values visible and help to assess the tradeoffs associated with these interactions are being increasingly used to help them face this complexity (Burkhard et al., 2013; Maes et al., 2012; Tallis and Polasky, 2011, 2009). It has also been reported that the reliability, the local relevance, and the effective use of ES knowledge can greatly benefit from meaningful stakeholder participation (Biggs et al., 2011; Koschke et al., 2014; Levrel and Bouamrane, 2008; McKenzie et al., 2014; Rosenthal et al., 2015; Ruckelshaus et al., 2015).

Given the growing importance of ES approaches and assessment tools, it is now essential to test their effectiveness in a variety of real-world decision-making contexts and practical management situations at the territorial level (MEA, 2005; Ruckelshaus et al., 2015). Although a number of studies have quantified and mapped multiple ES (Chan et al., 2006; Egoh et al., 2008; Geneletti, 2013; Goldstein et al., 2012; Leh et al., 2013; Nelson et al., 2009), such studies do not exist for France at the municipal level or, especially, for using open tools and data such as the Corine Land Cover (CLC) (EEA, 2012), which is an important European dataset for Land Use and Land Cover (LULC).

In this paper we report the results of a spatial explicit ES assessment with local stakeholders using a tool called InVEST (Integrated Valuation of Ecosystem Services and Tradeoffs), which relies on ecological information to map, quantify, and value the distribution of ecosystem services across a landscape (Tallis et al., 2014), and other own-produced models. The ES assessment is focused on what is called the tandscape services", which correspond to the services supplied by landscapes, i.e., the capacity of a landscape to provide goods and services to society (Lamarque et al., 2011). To measure these services, we use $€ S$ 
indicators", which represent quantitative spatially differentiated metrics or maps related to supply of, or demand for, ES" (EPA, 2009).

The goals of this exploratory and awareness raising study are:

(i) to identify and describe the evolution of ES in the Urban Community of Bordeaux (CUB) as an impact of LUCC between 1990 and 2006 using free tools and open data;

(ii) to describe a strategy for studying ES changes with stakeholder engagement; and

(iii) to highlight issues regarding the assessment of ES at a local scale and discuss how this approach can provide useful information for integrative urban planning and, ultimately, be integrated in existing formal urban planning processes.

\section{Data and methods}

\subsection{Study area}

The city of Bordeaux, capital of the region of Aquitaine, is located in southwestern France. The CUB is composed of 28 municipalities (communes) and covers about 57,632 ha (Fig. 1). It has a varied LULC composition including densely urbanized areas, agricultural and vineyard areas, forests, and wetlands. It is an area characterized by low slopes and low elevation $(<105 \mathrm{~m})$.

In the north of the CUB is located the Ambès peninsula, which has marsh landscapes and wildlife typically found in wetlands. This natural territory is subject to strict protection restrictions. The Jalles Park, in the west of the CUB, houses the Bruges Regional Natural Reserve, composed of marshes and diverse habitats with more than 4,000 animal species (La CUB, 2013). In the west are also located the Landes forest, which is the largest maritime-pine forest in Europe. In the south, the rivers Vallée de l'Eau Bourde and the Vallée de l'Eau Blanche offer opportunities for recreation, such as fishing and hiking. On the east side of the CUB, on the right bank of the Garonne river, is located the Parc des Coteaux covering 100 ha.

The natural environment hosts a great a variety of local plant and animal species. Some of them are protected, such as the Angelica heterocarpa, Mustela lutreola, and the Phengaris arion (La CUB, 2013; Ruys et al., 2012). Other, more common species, are also present in these natural spaces such as foxes, otters, and orchids. There are also many local and migratory bird species on the territory of the agglomeration (Le Gall et al., 2012).

The study area presents a set of practical issues in land use planning and the CUB expectation of reaching one million inhabitants by 2030 (727,256 inhabitants in 2011). To 
manage this expectation the CUB launched, in 2009, a prospective approach that resulted in a policy document, the "Metropolitan Project", which articulates a vision for the city to year 2030. Among others, the "55,000 ha for Nature" initiative aims to make compatible the demographic growth with the "respect and valuation of the natural spaces in the city, the wellbeing and the respect for the biological needs of plant and animal species" (CUB, 2012). Therefore, the CUB wishes to put the "collective relationship to nature" at the heart of its reflection in the coming decade. The willingness to better account for nature in the Metropolitan Project has helped to shape planning instruments such as the SCoT (Schéma de cohérence territoriale) and the PLU (Plan local d'urbanisme). In this context, a quantitative spatial assessment of ES of the territory may provide valuable information to help the CUB reach these objectives in the near future.

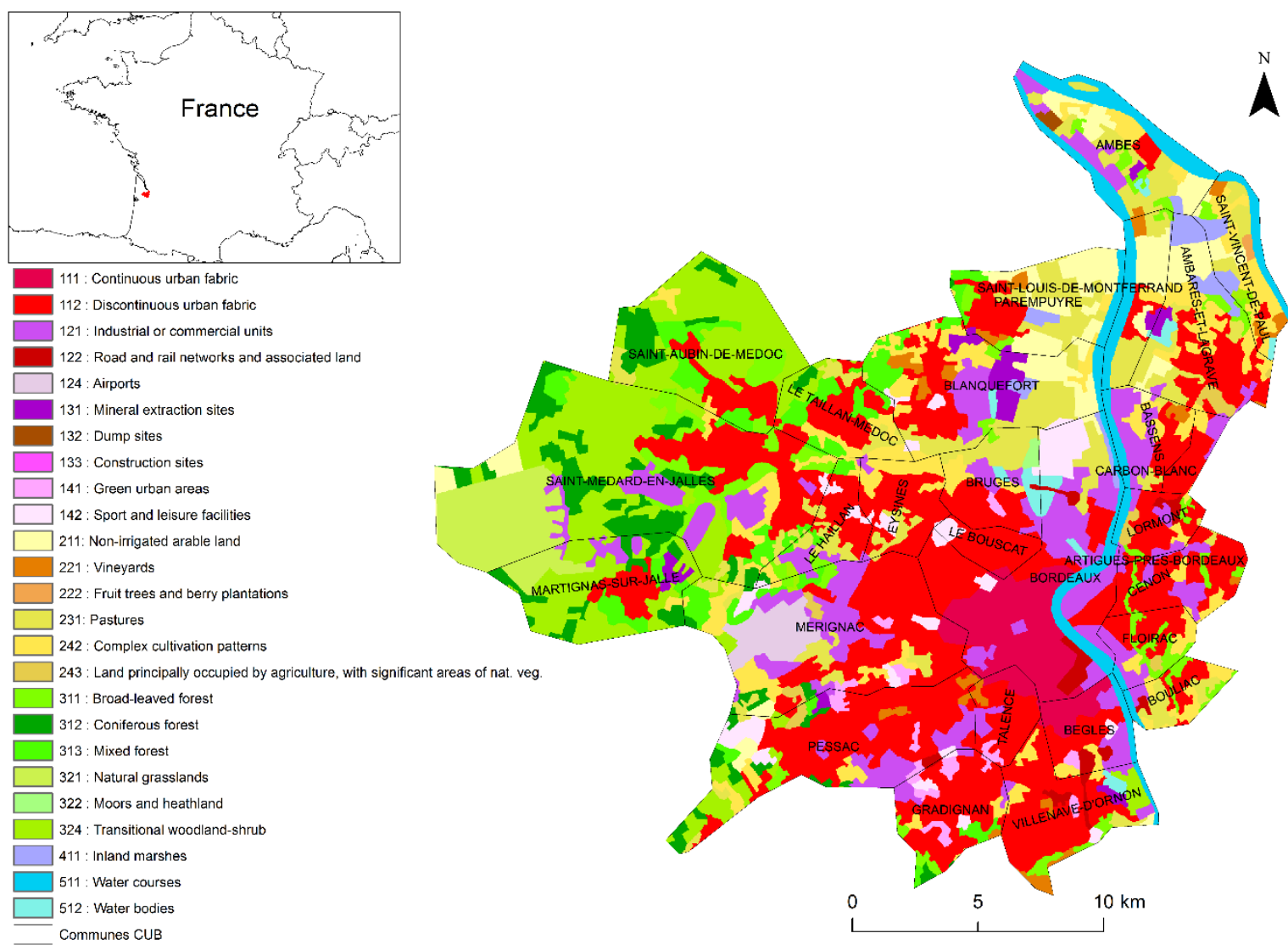

Fig. 1 The CUB and land use and land cover in year 2006 (Data sources: EEA, 2006 and IGN, 2013)

\subsection{An iterative process for integrating ES into spatial planning decisions}

A variety of tools have been developed in recent years to improve the integration of ES in multiple decision-making processes, by providing more systematic and reproducible 
approaches for the quantification and assessment of ES (Bagstad et al., 2013; Peh et al., 2013). These tools range from simple spreadsheets (WRI, 2012) to sets of complex spatial modeling software (Bagstad et al., 2011; Feng et al., 2011; Tallis et al., 2014).

InVEST tools have been designed essentially with the aim of informing national or regional planning instruments and policies (Tallis et al., 2014). In this study we did not try to inform directly the existing planning instruments and processes ruling the CUB area, as there was no formal demand for it. Rather, we used ES approaches and tools as a way to: (1) raise awareness on the need to take ES into account in land use planning and management; and (2) open a space for dialogue among multiple stakeholders, based on a shared mental model" and visual representation of the connections between land use and good ecosystem functioning (Biggs et al., 2011).

The research team included both independent scientific researchers and researchers employed by the local water company, Lyonnaise des Eaux (now SUEZ Eau France), which supported this study and hosted the workshops. The company's own motivation was to test ES approaches: (1) to better understand the relationships between its water management operations and multiple aspects of biodiversity and ecosystem functioning (Feger, 2016); and (2) to open an exploratory dialogue with the municipality (its main client) and other stakeholders on green infrastructure planning and management. The CUB Nature Division and the CUB Water Division demonstrated interest and provided technical support at an early stage of the project.

We did not seek to involve all possible stakeholders (e.g. tourism sector, individual users, etc.). Rather, we focused on consulting local stakeholders who represent various sectors that have an influence on land use planning and management and who could contribute from their own perspective to an informed dialogue on multiple ES: (1) stakeholders who have regulatory authority on the overall land-use planning and urban development dynamics (i.e. the CUB Water Division, the CUB Nature Division; the CUB Department of Urbanism); (2) stakeholders who operate on the CUB's areas that are of particular importance for biodiversity as well as for water management such as the Jalles Park (i.e. environmental NGOs); and (3) stakeholders who play an important role in economic sectors strongly connected to ecological systems and water quality protection (i.e. wastewater management and water resource protection engineers from the water company; representatives of the Chamber of Agriculture) (Feger et al., 2015).

The research team preselected a group of ES which they believed to be relevant for the CUB area, keeping in mind the availability of open datasets. These included provisioning 
(food provisioning), regulation (water quality, flood regulation, erosion regulation, climate regulation) and cultural (recreation, biodiversity) services. Some face-to-face interviews took place with the different stakeholders in the preliminary phase of the study before the $1^{\text {st }}$ workshop. These were conducted in order to present and discuss with them the ES assessment approach and the study objectives, as well as to better identify their respective concerns regarding future land use management in the CUB. The data collection activities as well as an extensive literature review about values of parameters required to run the ES models were carried out. Local scientific experts were consulted when adequate values were not found in the scientific literature. An historical analysis of ES between 1990 and 2006 was undertaken and presented to stakeholders during the $1^{\text {st }}$ workshop organized at the end of the first year of the project (Fig. 2).

The objective of the $1^{\text {st }}$ workshop was to raise awareness about the importance of ES and to ask for stakeholders' opinions about the choices made by the research team, such as the definition of the study area and the selection of the relevant ES. The $1^{\text {st }}$ workshop started with the presentation of the ES concepts and the preliminary results for the ES calculated for the study area. Then a collective discussion followed in which remarks were made about the usefulness of some ES, the dynamics of local ecological issues, the way ES were communicated (e.g., how to name them in a sense-making way for a general audience) and calculated. At the end of the workshop the research team asked each participant to fill in a questionnaire with suggestions for improving the usefulness of the study. All this information was used to adapt the selected ES modeling approach to the needs expressed by the stakeholders.

The $2^{\text {nd }}$ workshop, at the end of the $2^{\text {nd }}$ year, was dedicated to sharing and interpreting the results, and to discuss in an exploratory way their possible uses for influencing the municipality's planning decisions and stakeholders' practices and activities. Participants were asked to fill in a questionnaire about the interest they had in this study and in the dialogue with other stakeholders, about the way they intend to use these results in their own organizations and activities, and about the expected future developments of the ES. 


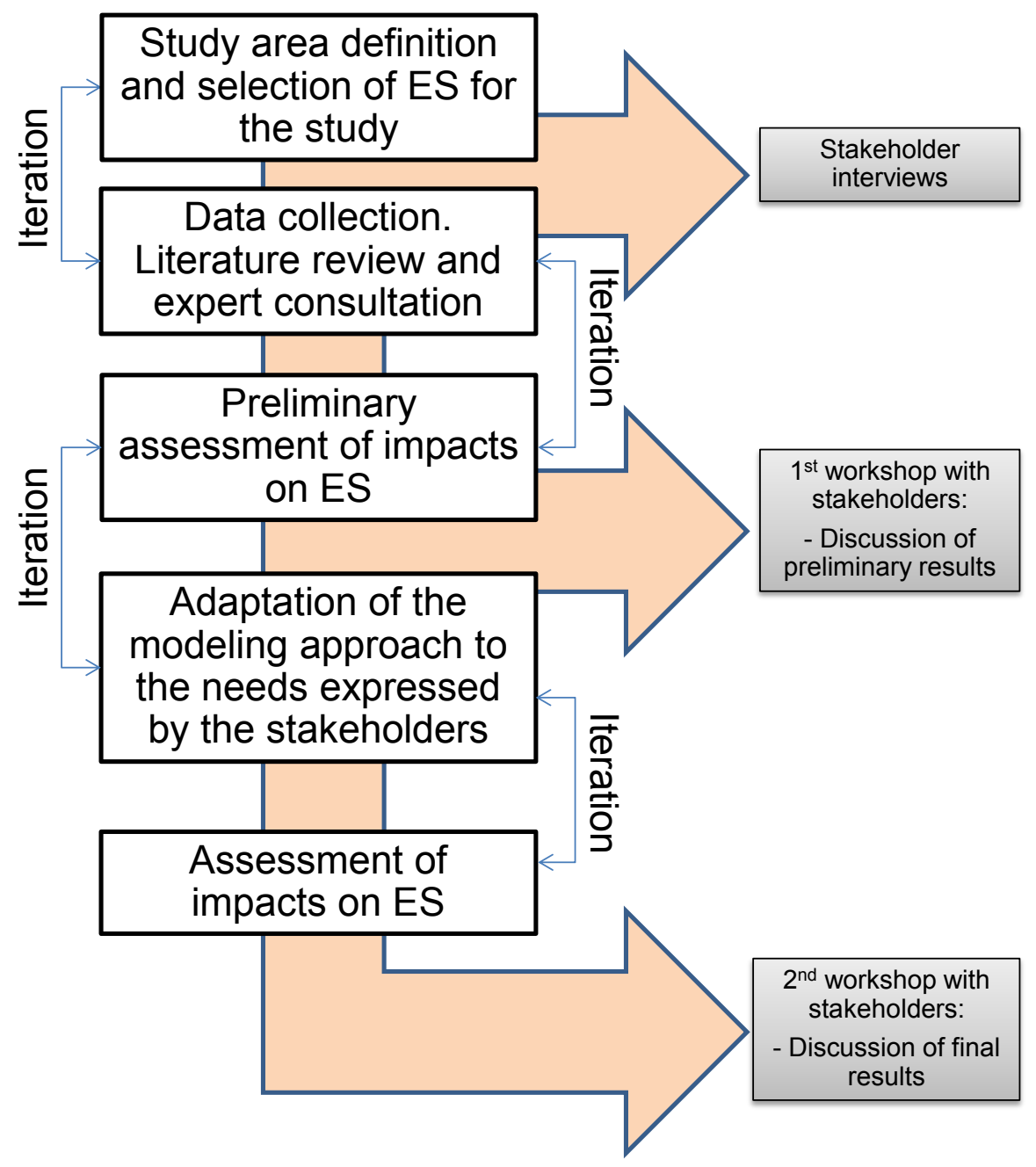

Fig. 2 Workflow of this study

\subsection{ES models and indicators for the CUB}

The selected ES were calculated using InVEST (Kareiva et al., 2011; Tallis et al., 2014) (carbon storage, water yield, and nutrient and sediment retention models) and other owndeveloped models (agriculture, recreation and biodiversity) to evaluate how LUCC affected ES in the CUB. We conduct a joint assessment of multiple ES, but do not attempt to equally assess the social, biophysical, and economic dimensions of those services (i.e. integrated assessment) (Fontaine et al., 2014).

We used Corine Land Cover (CLC) from the European Environmental Agency (EEA) which has a spatial resolution of $100 \mathrm{~m}$ with a minimum mapping unit of 25 ha (EEA, 2012). 44 LULC classes are distinguished in these datasets for the years 1990, 2000, and 2006, although not all of them are present in the study area (supplementary Table A.1 shows all the LULC classes present in the CUB). All geographical datasets used in this study are open data 
and are, or were, converted into a common coordinate system RGF_1993_Lambert_93. Table 1 reports the ES and respective ES indicators (units) used in this study.

Table 1 ES and ES indicators (units) used in this study

\begin{tabular}{ll}
\hline \multicolumn{1}{c}{ ES } & \multicolumn{1}{c}{ ES indicator, units } \\
\hline Food provisioning & Total area for agriculture, ha \\
Flood regulation & Water yield, $\mathrm{m}^{3} / \mathrm{ha} / \mathrm{year}$ \\
Water quality & Nutrient retention (phosphorus and nitrogen), \\
& $\mathrm{kg} / \mathrm{ha} / \mathrm{year}$ \\
Erosion regulation & Sediment retention, $\mathrm{t} / \mathrm{ha} / \mathrm{year}$ \\
Recreation & Residential areas served by the green and blue \\
& areas, ha \\
Climate regulation & Carbon stored, $\mathrm{t} / \mathrm{ha} / \mathrm{year}$ \\
Biodiversity & Suitable habitats for fauna and flora, ha \\
\hline
\end{tabular}

\section{Food provisioning}

The total area (A) of the CLC classes dedicated to agriculture is used as a proxy of the food provisioning service. This service was considered important because of the cultural attachment of the region to agriculture, especially to vineyards, and the important place given to small scale suburban agriculture in the 55,000 ha for nature" initiative. The values, reported in hectares, were aggregated to provide estimates by municipality (IGN, 2013).

\section{Flood regulation}

Water yield is the amount of water running off the landscape (Langbein and Iseri, 1995). It is important to control water yield in the CUB because this is a territory prone to floods. The Water Yield InVEST model is based on the Budyko curve and annual average precipitation (Tallis et al., 2014). We parameterized this model using average annual precipitation $\left(\mathrm{P}_{\mathrm{x}}\right)$ (Hijmans et al., 2005), annual reference evapotranspiration (Trabucco and Zomer, 2009), soil depth (Panagos et al., 2012), plant available water content (Panagos et al., 2012), plant root depth (Canadell et al., 1996; Fagherazzi et al., 2004; Hédin, 1972; Lebourgeois and Jabiol, 2006; Mollier, 1999; Tallis et al., 2014), watersheds (IGN, 2006), and LULC to calculate the average annual water yield. The evapotranspiration coefficient $\left(\mathrm{ETo}_{\mathrm{x}}\right)$ estimates per LULC class were developed based on the Leaf Area Index (LAI) (Watson, 1947) and integrated in the model according to the procedure described in the InVEST manual (Tallis et al., 2014). 
The Normalized Vegetation Index (NDVI) (Rouse et al., 1974) data were obtained from the MODIS / NDVI Time Series Database Project Global Agriculture Monitoring (GLAM, 2013). These images have a spatial resolution of $250 \mathrm{~m}$ and a temporal resolution of 16 days. A total of 23 images for the year 2006 in GeoTiff format were averaged using a procedure which excluded the nodata pixels to use the maximum information available. The LAI calculation was based on the method described in (NASA, 2012): LAI $=-1.323 \ln ((0.88-$ NDVI)/0.714) .

We report water yield in $\mathrm{m}^{3} / \mathrm{ha} /$ year. Pixel values were aggregated by municipality (IGN, 2013). Although, some municipalities span more than one sub-watershed, they all belong to the same higher-level watershed, meaning that all the water will be draining into the same watershed outlet. The root depths and evapotranspiration coefficients are available as supplementary material (Table B.1).

\section{Water quality}

The InVEST nutrient retention model evaluates LULC effects on water quality (Tallis et al., 2014). Datasets used include a digital elevation model (DEM) (NASA, 2012), precipitation (Hijmans et al., 2005), evapotranspiration (Trabucco and Zomer, 2009), depth to root (Panagos et al., 2012), plant available water content (Panagos et al., 2012), watersheds (IGN, 2006), and LULC. The DEM used, ASTER (NASA, 2012), had a spatial resolution of $30 \mathrm{~m}$ and was hydrologically corrected (Hellweger, 1997) with data of the Water Information System of the Adour Garonne watershed (IGN, 2006).

The model starts by calculating the average annual water yield based on each LULC. Then the average annual quantity of nutrients exported from each LULC cell is determined using values found in the literature and through expert consultation for nitrogen $(\mathrm{N})$ and phosphorus (P) export coefficients (Deletraz and Dabos, 2001; Foy and Girvan, 2004; Jeje, 2006; Jordan et al., 2000; Kelsey and Hall, 2010; Leh et al., 2013; Matias and Johnes, 2011; Payraudeau et al., 2002; Reckhow et al., 1980; Tallis et al., 2014; Wochna et al., n.d.). The nutrient load is obtained by routing water along flow paths based on slope (Leh et al., 2013). Finally, the nutrient load quantity retained by the landscape is determined using the nutrient retaining capacity of each LULC (Tallis et al., 2014).

We report nutrient retention (phosphorus and nitrogen) in $\mathrm{kg} / \mathrm{ha} /$ year. Pixel values with mean nutrient retention were aggregated by municipality (IGN, 2013). Evapotranspiration, nutrient loadings, and filtering coefficients are available as supplementary material (Table B.1). 


\section{Erosion regulation}

Soil erosion can be caused by rain and runoff. Impacts of erosion include (Lal, 1998; Mann et al., 2002): the reduction of water quality, reduction of soil ability to store water and nutrients, reduction of agronomic productivity, damage in infrastructures, and siltation. The Sediment Retention InVEST model (Tallis et al., 2014) was used to determine the ability of the landscape to retain sediments in a watershed as a function of rainfall (Hijmans et al., 2005), soil characteristics (Panagos et al., 2012), and topography (NASA, 2012). The model uses the Universal Soil Loss Equation (USLE) (Wischmeier, 1978) to calculate the potential soil loss of each LULC (1):

$$
\mathrm{USLE}=\mathrm{R} * \mathrm{~K} * \mathrm{LS} * \mathrm{C} * \mathrm{P}
$$

where USLE is the potential average annual soil loss, $\mathrm{R}$ is the rainfall erosivity factor, $\mathrm{K}$ is the soil erodibility factor (Panagos et al., 2012), LS is the slope length and steepness factor, $\mathrm{C}$ is the LULC management factor (DEQ, 2012; FORSEE, 2007; Leh et al., 2013; Tallis et al., 2014), and $\mathrm{P}$ is the supporting practice factor (DEQ, 2012; FORSEE, 2007; Leh et al., 2013; Tallis et al., 2014). The sediment retention corresponds to the difference between potential soil loss (USLE) of the landscape and the maximum potential soil loss assuming a bare landscape. The rainfall erosivity $(\mathrm{R})$ is a climatic factor strongly related to soil loss and was determined as (Renard and Freimund, 1994) (2):

$$
\mathrm{R}=0.04830 * \mathrm{P}^{1.610}
$$

where $\mathrm{R}$ is rain erosivity and $\mathrm{P}$ is the average annual precipitation (mm) (IGN, 2013).

We report sediment retention in $\mathrm{kg} / \mathrm{ha} /$ year. Pixel values with mean sediment retention were aggregated by municipality (IGN, 2013). Cover-management (C), support practice and the sedimentation retention values used are available as supplementary material (Table B.1).

\section{Recreation}

We calculated this ES using the approach described in the work made for a city in Finland (Niemelä et al., 2010). In that study, the authors identified the suitable areas for recreational activities, "green areas", using CLC. Only areas with more than 1.5 ha were considered and 
these should be located within a distance of $300 \mathrm{~m}$ of a residential area, which is defined as the maximum distance for a recreational walk ( $5 \mathrm{mn}$ walk).

In the current study, the green and blue areas considered the following CLC level 2 classes (the code of the class inside parentheses): Artificial, non-agricultural vegetated areas (14), Forests (31), Scrub and/or herbaceous vegetation associations (32), Inland wetlands (41), Coastal wetlands (42), Continental waters (51), and Marine waters (52). We mapped these areas for years 1990 and 2006. It was noticed that the urban growth between these two dates created a considerable number of new accesses to green and blue areas. To address this effect, the number of hectares of the residential areas of 1990 that were served by the green and blue areas in 1990 and in 2006 were calculated. The results were reported by municipality in hectares.

\section{Climate regulation}

Carbon storage is an important global climate regulation service (Gómez-Baggethun and Barton, 2013). Estimates of the carbon stored by the vegetation for each LULC class with values found in literature (Cruickshank et al., 2000; Pereira et al., 2009) were used in the InVEST Carbon model (Tallis et al., 2014). The carbon stored by the CUB landscape is reported in $t / h a / y e a r$ and is aggregated to provide estimates by municipality (IGN, 2013). The carbon stored by each LULC is available as supplementary material (Table B.1).

\section{Biodiversity}

(Dallimer et al., 2012) demonstrated a positive relationship between well-being and the biodiversity richness that green space users perceive to be present. We treat biodiversity as a cultural service (non-use value) and measure it through the suitable LULC available area for the species that exist in the CUB. Biodiversity observation opportunities will be available for CUB inhabitants if these LULC are preserved. The procedure adopted for calculating this ES indicator consisted of extracting the observed fauna species in the study area from the Atlas of Aquitaine's Fauna (LPO Aquitaine, 2013) during the year 2012. The set of observed fauna in the CUB included 5 species of amphibians, 6 species of reptiles, 5 species of mammals, and 72 bird species. Then, the Natura 2000 database was used to determine the habitats in which these species could be found (INPN, 2013). The relationship between the habitat and the CLC classes was determined using the correspondence available in the report Projet de caractérisation des fonctions écologiques des milieux en France" (CGDD, 2010). Retained CLC level 2 classes for the species analyzed were (the code of the class inside parentheses): 
Pastures (23), Forests (31), Scrub and/or herbaceous vegetation associations (32), Inland wetlands (41), and Inland waters (51). We calculated the area of these classes for years 1990 and 2006. The results were reported by municipality in hectares.

\subsection{Variation in ES levels}

After calculating the ES of each type for each year in the CUB, the changes from 1990 to 2006 were calculated as (3):

$$
C E S_{x}=\left[\frac{E S_{2006 x}-E S_{1990 x}}{E S_{1990 x}}\right] * 100
$$

where $C E S_{x}$ is the ES change index for delivering ES of type $x, E S_{1990 x}$ is the baseline situation for delivering ES of type $x$ in 1990, and $E S_{2006 x}$ is the situation for delivering ES of type $x$ in 2006.

\section{Results}

\subsection{Elaborating a shared representation and promoting ES based dialogue in the CUB:}

\section{$1^{\text {st }}$ workshop}

The selection of relevant ES for the study area, the discussion about the best way to present and communicate results (e.g., to report results using municipalities instead of subwatersheds) and/or adjustment of specific ES indicators (e.g., access to green areas and biodiversity models) were essential for developing an iterative approach that fit the stakeholders information needs. Table 2 reports the results of the interaction between the stakeholders and the scientific team during the $1^{\text {st }}$ workshop including the analysis of the questionnaire. All the suggestions were considered for adapting the first version of the modeling approach. The way these changes were addressed were presented to the stakeholders during the $2^{\text {nd }}$ workshop. 
Table 2 Main suggestions mentioned by stakeholders and respective solution

\begin{tabular}{ll}
\hline \multicolumn{1}{c}{ Problem } & \multicolumn{1}{c}{ Solution } \\
\hline $\begin{array}{l}\text { Access to green and blue areas did not consider } \\
\text { urban sprawl and demographic growth aspects, }\end{array}$ & $\begin{array}{l}\text { We report this service using the number of hectares } \\
\text { of the residential areas of } 1990 \text { that were served by } \\
\text { making an unfair comparison between } 1990 \text { and } \\
\text { the green and blue areas of } 2006 .\end{array}$ \\
$\begin{array}{l}\text { ES were presented using the name of the indicator, } \\
\text { which was confusing for a less familiarized }\end{array}$ & $\begin{array}{l}\text { All ES are reported using the name of the ES and not } \\
\text { the name of the biophysical indicator (e.g. erosion }\end{array}$ \\
audience. & $\begin{array}{l}\text { regulation instead of sediment retention, flood } \\
\text { regulation instead of water yield). }\end{array}$ \\
The analysis of ES was reported using the sub- & $\begin{array}{l}\text { It was decided that it would be more useful to report } \\
\text { ES using only the municipalities of the CUB (28 }\end{array}$ \\
matersheds of the SCOT territory (93 & $\begin{array}{l}\text { municipalities) as analysis unit to fit elected officials } \\
\text { and local decision-makers' potential needs. } \\
\text { This was a situation for which we did not have a }\end{array}$ \\
The scale of analysis did not consider recent CUB \\
efforts to create green areas.
\end{tabular}

\subsection{LULC and ES dynamics between 1990 and 2006}

The quantitative areal data of the LUCC, as well as gains and losses in each category between 1990 and 2006, are depicted in Table 3. This table shows that artificial surfaces represented $47.8 \%$ of the total area in 2006 when, in 1990, they represented only $44.3 \%$. During this time period agricultural areas fell considerably (-11.2\%) and lost 1967ha for artificial areas. Forest and semi-natural areas (-2.9\%) and wetlands (-6.1\%) also decreased. These classes lost for the artificial areas, respectively, 712ha and 54ha. 
Table 3 Land use and cover change of CLC level 1 classes (1: Artificial areas; 2: Agricultural areas; 3 : Forest and seminatural areas; 4: Wetlands; 5: Water bodies) in the CUB between 1990 and 2006

\begin{tabular}{|c|c|c|c|c|c|c|c|c|}
\hline \multicolumn{8}{|c|}{1990} & \multirow[b]{2}{*}{$\begin{array}{c}\text { Var (\%) } \\
90-06\end{array}$} \\
\hline Class & 1 & 2 & 3 & 4 & 5 & ha & $\%$ & \\
\hline 1 & 24710 & 1967 & 712 & 54 & 92 & 27535 & 47.8 & 7.9 \\
\hline 2 & 474 & 11418 & 315 & 73 & 46 & 12326 & 21.4 & -11.2 \\
\hline 3 & 251 & 354 & 13752 & 8 & 5 & 14370 & 24.9 & -2.9 \\
\hline 4 & 6 & 81 & 15 & 511 & 1 & 614 & 1.1 & -6.1 \\
\hline 5 & 77 & 64 & 7 & 8 & 2631 & 2787 & 4.8 & 0.4 \\
\hline ha & 25518 & 13884 & 14801 & 654 & 2775 & 57632 & & \\
\hline$\%$ & 44.3 & 24.1 & 25.7 & 1.1 & 4.8 & & & \\
\hline
\end{tabular}

Figure 3 shows the results for the ES analyzed in the CUB between 1990 and 2006. Only erosion regulation (sediment retention indicator) had a positive variation in the study area $(+1.2 \%)$. Water yield is considered a disservice, as it degrades the flood regulation. Its increase $(+1.3 \%)$ is, therefore, considered as having a negative effect in this service and was multiplied by -1 . All other services evolved negatively during the time period analyzed.

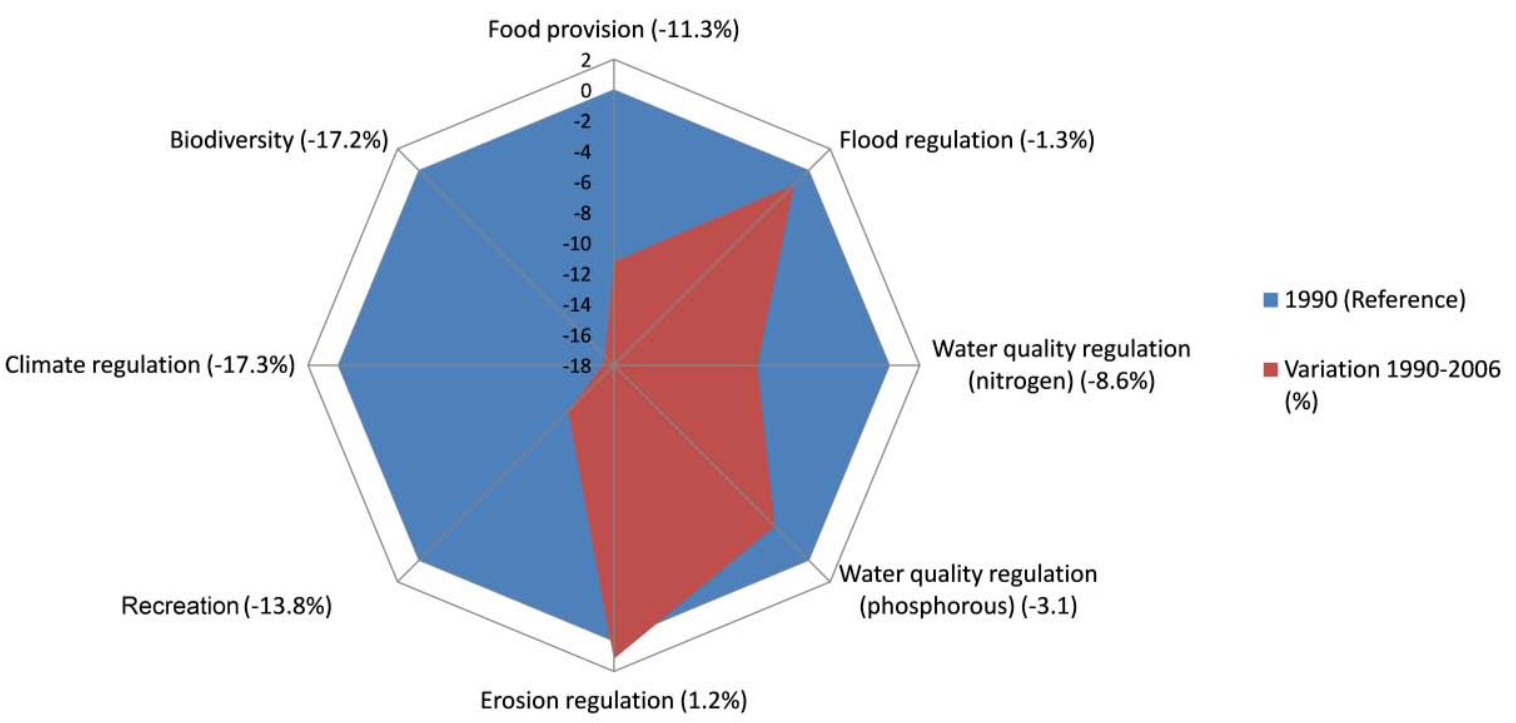

Fig. 3 Ecosystem services variation (\%) between 1990 and 2006

Figure 4 shows the ES variation from 1990 to 2006 by municipality using a standard deviation classification scheme. The variation of food provisioning (agriculture) and 
biodiversity are represented using percentage points. All other ES are represented using variation in percentage.

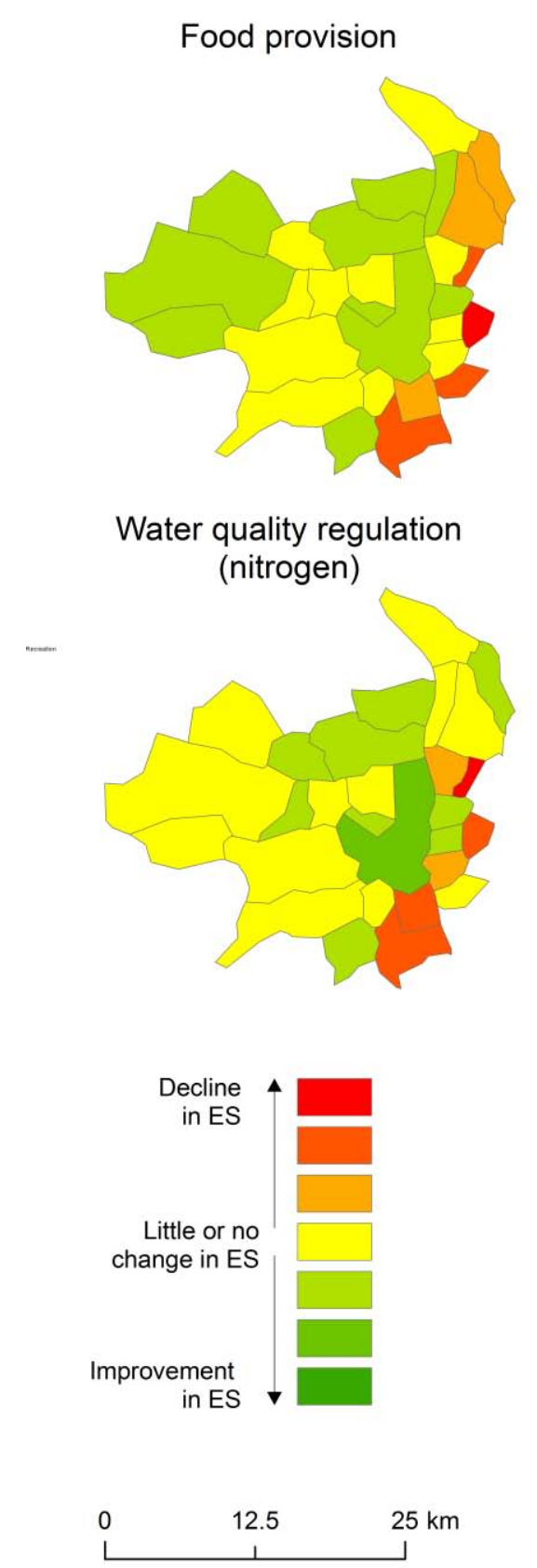

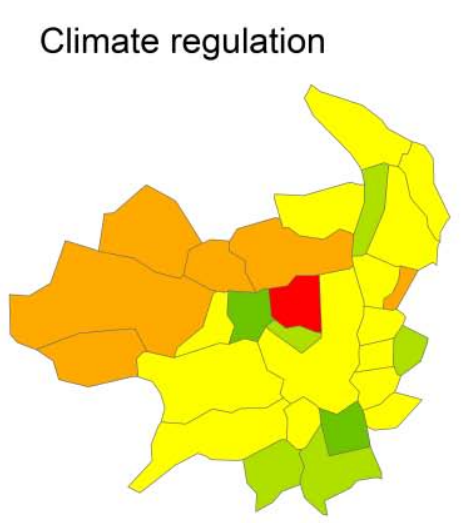

Water quality regulation (phosphorous)

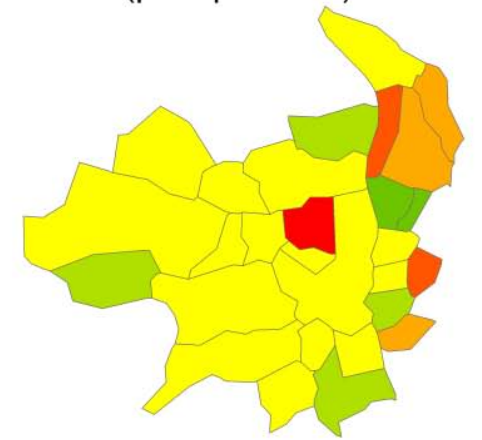

Recreation

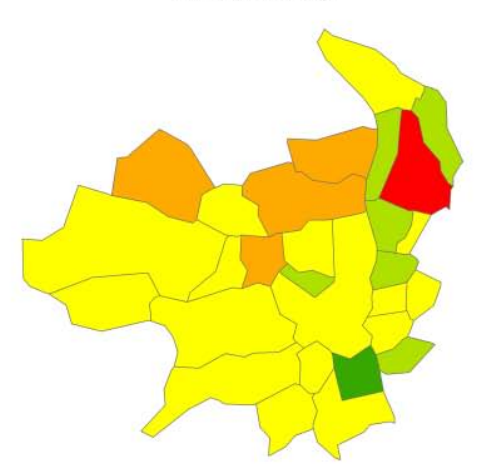

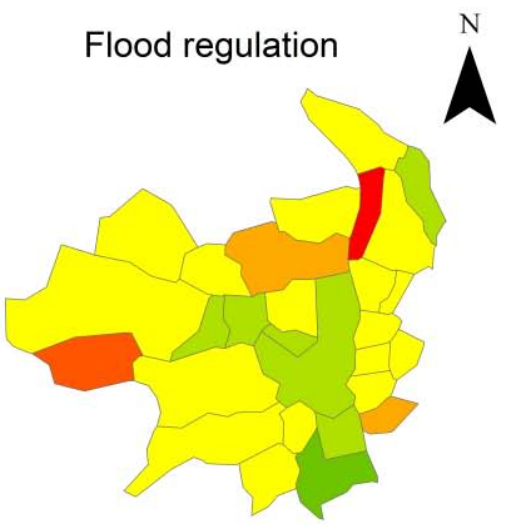

Erosion regulation

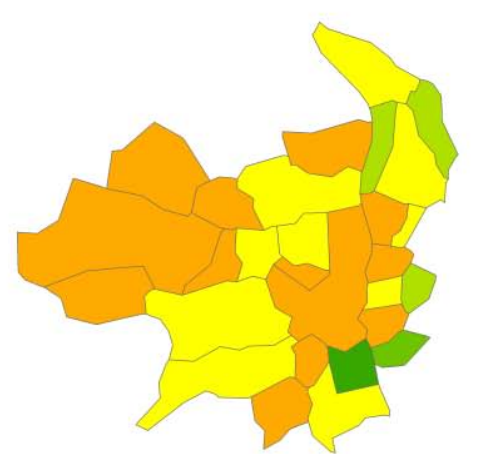

Biodiversity

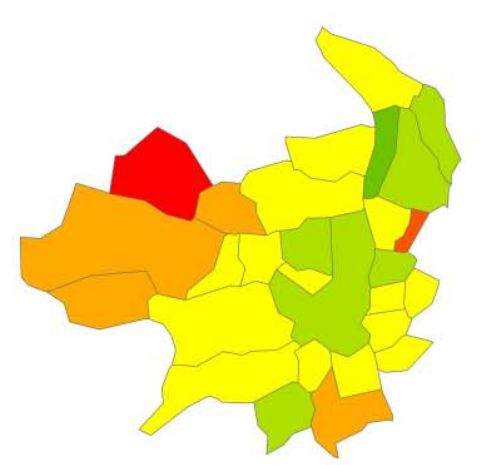

Fig. 4 ES variation between 1990 and 2006

\subsection{A collective exploration and interpretation of the results: $2^{\text {nd }}$ workshop}

Extensive discussions with the stakeholders during the second workshop provided useful insights on the potential causes of the results obtained and how these could be interpreted. Each stakeholder gave specific feedback on the ES that were more closely related to the 
activities of the organization and sector he/she represented. Environmental NGOs were more concerned with the biodiversity results, while the CUB Nature Division and the CUB Urbanism Department paid particular attention to biodiversity, flood regulation, and recreation. The Agriculture Chamber looked more attentively into the food provision from agriculture.

The degradation of the flood regulation service is occurring mainly in the areas surrounding pre-existing urban areas. It was suggested that this was caused by both the increasing land artificialization and the degradation of wetlands, notably in the northeast parts of the CUB. It was also pointed out that our models only took into account flooding risks due to rainwater, to which should also be added important flooding risks due to the proximity of the Garonne estuary. Regarding water quality regulation, the nitrogen retention in the southeast, and phosphorous retention in the northeast, are decreasing along the Garonne river. Food provisioning (agriculture) is decreasing more strongly on the East side of the CUB along the Garonne river. Although it was pointed out that the model did not represent small-scale agricultural plots, the overall results were consistent with the increasing loss of agricultural land due to urbanization. The climate regulation (carbon storage) decreased more in the municipalities of Bordeaux and on the northwest side of the CUB, where the Landes forest is located. This forest was severely struck by the Martin storm in December 1999, which caused considerable damage and loss of lives. This effect is also visible in the recreation and in biodiversity services.

All the stakeholders expressed curiosity to better understand how the current actions that they are undertaking will affect the evolution of the different ES. The CUB Nature Division is leading efforts with the local nature protection NGOs to ensure wetland protection and to create new Natura 2000 areas in the north and the south of the city. It is also opening new nature hiking trails (-boucle verte") that circle the urban city center to provide more public access to green areas. The Agriculture Chamber is operating a program to help young farmers open and run their business and save agricultural land from urbanization. The CUB Department of Urbanism has recently led efforts to identify and integrate the major ecological corridors of the area in the elaboration of its new urban plan. The water company has recently helped with the restoration of the ecological continuity of a river (Jalle-de-Blanquefort) flowing in the north of the city and with installing sophisticated monitoring systems of its surface water quality. All stakeholders showed interest in conducting further studies to gather more detailed and recent LULC data in order to see if the results of these various efforts and policies would eventually appear on future maps. 


\section{Discussion}

\subsection{ES changes in the CUB as an impact of LUCC with open data and free tools}

In this study we quantified and mapped the evolution of CUB ES using open data and free tools. We contribute with a case study that quantifies and maps multiple ES changes over time as a consequence of LUCC using ecological production functions. However, some precautions should be taken before implementing any payments or compensation measures for ES on the sole basis of our exploratory study. We have only measured the potential of the ecosystem to provide such ES. A more detailed analysis should be made to study the relationship between stakeholders' land management practices, ES provision, and ES use by people.

Furthermore, it is also important to consider modeling and data limitations. All the models used have (as do all models) several limitations. For instance, regarding the InVEST models, we had to use a value transfer approach when we did not find the values for specific parameters in our study area (e.g. nutrient and sediment export values for specific CLC classes). All InVEST models used also have several limitations and simplifications which are described in the software documentation (Tallis et al., 2014). Concerning the own-developed models, there are also limitations that need to be considered. For instance, the agriculture ES indicator only reflected the value of the area in hectares dedicated to agriculture for each year of the CLC, regardless of the techniques used that could increase or decrease productivity. The recreation model did not consider potential visitors that use public or private transportation to frequent these places. The minimum mapping unit of $25 \mathrm{ha}$ of the CLC also did not consider new green areas smaller than this value. Lastly, the biodiversity model only considered the CLC classes frequented by the species observed in the CUB, regardless of other important aspects, such as historical species abundance.

Data scarcity and scale issues were challenging aspects in this project. The geographical datasets needed for this modeling approach were not always available and some had to be calculated using indirect methods (e.g. evapotranspiration coefficients for the water yield model); others had disparate collection dates and/or different and/or inadequate scales (e.g., the hydrological services require data at the watershed level, while the study of recreational services would benefit from more detailed data). The option for aggregating data at the CUB municipality level was taken after the $1^{\text {st }}$ workshop with the stakeholders. Indeed, this option generalizes values of ES indicators that were obtained at the pixel level. However, showing 
the results at the municipality level made visible clear advantages for understanding and communicating where ES have been degraded and where measures are needed to mitigate problems. The use of biophysical indicators to study ES is scale dependent (GómezBaggethun and Barton, 2013) and future versions of the study would also benefit from the use of more recent data (e.g. the most recent CLC dated from 2006, when this study was done) with improved resolution.

\subsection{A strategy for studying ES changes with stakeholder engagement}

The study benefitted from the participation of stakeholders who were involved since the beginning of the project. The assessment of multiple ES using spatial data and stakeholders' involvement is an essential feature in the Natural Capital Project approach philosophy (Kareiva et al., 2011). This study provided several insights on a possible strategy for engaging stakeholders in these kinds of projects. Firstly, it helped to raise awareness among stakeholders who were not familiarized with ES concepts. Secondly, it showed them the possibility of studying multiple ES using a spatial explicit approach. The stakeholders' engagement through the use of a common language was clearly facilitated by the use of maps, which made the exchange of information and ideas easier during the workshops. Thirdly, these stakeholders, who were used to work separately in their specific areas of intervention, understood the usefulness and the advantages of discussing ES together. Their active participation and willingness to understand the patterns, while recognizing the limitations of the exercise, and their efforts to find out how the preliminary results relate to their own activities and ongoing environmental policy and management projects testify their interest in this type of approach.

4.3 Contribution to integrative urban planning and integration in existing formal urban planning processes

We found that with the exception of the erosion regulation service $(+1.2 \%)$, all other ES have decreased in the CUB area between 1990 and 2006. During the $2^{\text {nd }}$ workshop, participants interpreted these negative trends as evidence of the current lack of integration of ES in the LUCC decision processes and discussed the need to design and implement more effective policy instruments (e.g. payments for ES, ecological compensation mechanisms, etc.) that could lead to a tradeoff between the continuous urbanization dynamics and ES conservation. 
Although it was not our aim to integrate the results directly in the existing planning instruments, this study enabled an informed dialogue between different stakeholders who are now more able to better understand the link between land changes and multiple ES. The CUB Department of Urbanism and the CUB Nature Division suggested the possibility of using such studies to inform the elaboration of future urban planning documents (notably the PLU Plan Local d'Urbanisme). These are important results that call for a stronger integration of ES in spatial planning in the CUB.

This study also pointed out the role of the 28 municipalities belonging to this territory in their responsibility to manage ES. This spatiotemporal diagnosis helped to make more explicit how different municipalities' LUCC choices contribute or impact ES production. These indicators should encourage them to look for better tradeoffs between development and ES protection than the ones that are carried out in a business as usual scenario at the urban scale.

\section{Conclusion}

This study assessed the impact of LUCC on multiple ES using a spatiotemporal approach enabling an innovative perspective on the functions and uses of the natural environments of the CUB. We showed that it is possible to use free tools and open geospatial data to study ES at a municipal scale. Although we have not used GIS free open source software to perform the spatial analysis, an approach based exclusively on this type of software (e.g., using Quantum GIS, gvSIG, or others) would have been possible since InVEST, as well as the own-developed ES models, are independent from the GIS software used. The results open a new space for dialogue on a common conceptual and scientific basis for a variety of stakeholders who have different perspectives and management activities of the CUB socio-ecological system. Although the results and the interest shown by stakeholders were promising, the outputs of scientific models may point to solutions different from the ones taken by policymakers and urban planners (Ruiz-Labourdette et al., 2010). Beyond the completion of this study, which will also include scenario and economic analysis of ES, the challenge will be to continue to work on the usefulness of this assessment and the way it can effectively influence decisionmaking activities contributing to the maintenance of ecosystem functioning.

\section{Acknowledgments}

This research was funded by Suez Eau France (Lyonnaise des Eaux). The authors would also like to thank all involved stakeholders and experts that contributed decisively with their opinions and knowledge to the outcome of this project. 


\section{References}

Bagstad, K., Villa, F., Johnson, G., Voigt, B., 2011. ARIES-Artificial Intelligence for Ecosystem Services: A Guide to Models and Data, Version1.0 Beta.

Bagstad, K.J., Semmens, D.J., Waage, S., Winthrop, R., 2013. A comparative assessment of decision-support tools for ecosystem services quantification and valuation. Ecosyst. Serv. 5, 27-39. doi:10.1016/j.ecoser.2013.07.004

Biggs, D., Abel, N., Knight, A.T., Leitch, A., Langston, A., Ban, N.C., 2011. The implementation crisis in conservation planning: could -mental models" help? Conserv. Lett. 4, 169-183. doi:10.1111/j.1755-263X.2011.00170.x

Burkhard, B., Crossman, N., Nedkov, S., Petz, K., Alkemade, R., 2013. Mapping and modelling ecosystem services for science, policy and practice. Ecosyst. Serv. 4, 1-3. doi:10.1016/j.ecoser.2013.04.005

Canadell, J., Jackson, R.B., Ehleringer, J.B., Mooney, H.A., Sala, O.E., Schulze, E.-D., 1996. Maximum rooting depth of vegetation types at the global scale. Oecologia 108, 583-595. doi:10.1007/BF00329030

CGDD, 2010. Projet de caractérisation des fonctions écologiques des milieux en France, Commissariat Général au Développement Durable MNHN, Museum National d'Histoire Naturelle, Etudes et documents du CGDD N²0. Paris.

Chan, K.M.A., Shaw, M.R., Cameron, D.R., Underwood, E.C., Daily, G.C., 2006. Conservation Planning for Ecosystem Services. PLoS Biol 4. doi:10.1371/journal.pbio.0040379

Cruickshank, M.M., Tomlinson, R.W., Trew, S., 2000. Application of CORINE land-cover mapping to estimate carbon stored in the vegetation of Ireland. J. Environ. Manage. 58, 269-287. doi:10.1006/jema.2000.0330

CUB, 2012. 55000 hectares pour la nature, Communauté Urbaine de Bordeaux.

Dallimer, M., Irvine, K.N., Skinner, A.M.J., Davies, Z.G., Rouquette, J.R., Maltby, L.L., Warren, P.H., Armsworth, P.R., Gaston, K.J., 2012. Biodiversity and the Feel-Good Factor: Understanding Associations between Self-Reported Human Well-being and Species Richness. Bioscience 62, 47-55. doi:10.1525/bio.2012.62.1.9

Deletraz, G., Dabos, P., 2001. Modélisation statistique de la pollution azotée en proximité d'un axe routier et évaluation des incidences sur l'environnement - Application au site de Biriatou (A63 - Pyrénées-Atlantiques). Laboratoire THEMA, Université de Franche- 
Comté, INRETS, CERTU, Editions Paradigme, pp. 63-93.

DEQ, 2012. Beaverhead Planning Area Sediment TMDLs and Framework Water Quality Improvement Plan. Montana Department of Environmental Quality.

EEA, 2012. Corine Land Cover 2006, European Environment Agency (EEA).

Egoh, B., Reyers, B., Rouget, M., Richardson, D.M., Le Maitre, D.C., van Jaarsveld, A.S., 2008. Mapping ecosystem services for planning and management. Agric. Ecosyst. Environ. 127, 135-140. doi:10.1016/j.agee.2008.03.013

EPA, 2009. Valuing the Protection of Ecological Systems and Services A Report of the EPA Science Advisory Board. US Environmental Protection Agency, Washington, DC. Fagherazzi, S., Marani, M., Blum, L.K., 2004. The Ecogeomorphology of Tidal Marshes. American Geophysical Union.

Feger, C., 2016. Nouvelles comptabilités au service des écosystèmes. Une recherche engagée auprès d'une entreprise du secteur de l'environnement. AgroParisTech, Paris.

Feger, C., Cabral, P., Basque, D., Levrel, H., Chambolle, M., 2015. Grand cycle de l'eau, évaluation des services écosystémiques et aménagement du territoire : un premier retour d'expérience. Tech. Sci. Méthodes 56-67. doi:10.1051/tsm/201509056

Feng, M., Liu, S., Euliss, N.H., Young, C., Mushet, D.M., 2011. Prototyping an online wetland ecosystem services model using open model sharing standards. Environ. Model. Softw. 26, 458-468. doi:10.1016/j.envsoft.2010.10.008

Fontaine, C.M., Dendoncker, N., De Vreese, R., Jacquemin, I., Marek, A., Van Herzele, A., Devillet, G., Mortelmans, D., François, L., 2014. Towards participatory integrated valuation and modelling of ecosystem services under land-use change. J. Land Use Sci. 9, 278-303. doi:10.1080/1747423X.2013.786150

FORSEE, 2007. Un réseau de zones pilotes pour la gestion durable des forêts de l'Arc Atlantique. FEDER - INTERREG IIIB Atlantic Area.

Foy, R., Girvan, J., 2004. An evaluation of nitrogen sources and inputs to tidal waters in Northern Ireland.

Geneletti, D., 2013. Assessing the impact of alternative land-use zoning policies on future ecosystem services. Environ. Impact Assess. Rev. 40, 25-35. doi:10.1016/j.eiar.2012.12.003

GLAM, 2013. 250-meter MODIS/NDVI Time Series Database.

Goldstein, J.H., Caldarone, G., Duarte, T.K., Ennaanay, D., Hannahs, N., Mendoza, G., Polasky, S., Wolny, S., Daily, G.C., 2012. Integrating ecosystem-service tradeoffs into land-use decisions. Proc. Natl. Acad. Sci. 109, 7565-7570. 
doi:10.1073/pnas.1201040109

Gómez-Baggethun, E., Barton, D.N., 2013. Classifying and valuing ecosystem services for urban planning. Ecol. Econ. 86, 235-245. doi:10.1016/j.ecolecon.2012.08.019

Hédin, L., 1972. Influence des racines sur la teneur de la matière organique du sol. Fourrages $50,83-96$.

Hellweger, F., 1997. AGREE - DEM surface reconditioning system. Center for Research in Water Resources.

Hijmans, R.J., Cameron, S.E., Parra, J.L., Jones, P.G., Jarvis, A., 2005. Very high resolution interpolated climate surfaces for global land areas. Int. J. Climatol. 25, 1965-1978. doi:10.1002/joc.1276

IGN, 2013. GEOFLA® Communes [WWW Document].

IGN, I.N. de l'Information G. et F., 2006. BD Carthage v 3.0, descriptif de livraison SHAPEFILE - sphère eau.

INPN, I.N. du P.N., 2013. INPN - Téléchargements de bases de données.

Jeje, Y., 2006. Export Coefficients for Total Phosphorus, Total Nitrogen and Total Suspended Solids in the Southern Alberta Region: A Review of Literature.

Jordan, C., McGuckin, S.O., Smith, R. V, 2000. Increased predicted losses of phosphorus to surface waters from soils with high Olsen-P concentrations. Soil Use Manag. 16, 27-35. doi:10.1111/j.1475-2743.2000.tb00168.x

Kareiva, P., Tallis, H., Ricketts, T.H., Daily, G.C., Polasky, S., 2011. Natural Capital: Theory and Practice of Mapping Ecosystem Services. OUP Oxford, New York.

Kelsey, P., Hall, J., 2010. Nutrient-export modelling of the Leschenault catchment, Water Science Technical series. Department of Water, Western Australia.

Koschke, L., Van der Meulen, S., Frank, S., Schneidergruber, A., Kruse, M., Fürst, C., Neubert, E., Ohnesorge, B., Schröder, C., Müller, F., Bastian, O., 2014. Do You Have 5 Minutes To Spare? - The Challenges Of Stakeholder Processes In Ecosystem Services Studies. Landsc. Online 1-25. doi:10.3097/LO.201437

La CUB, C.U. de B., 2013. La CUB.

Lal, R., 1998. Soil Erosion Impact on Agronomic Productivity and Environment Quality. CRC. Crit. Rev. Plant Sci. 17, 319-464. doi:10.1080/07352689891304249

Lamarque, P., Quétier, F., Lavorel, S., 2011. The diversity of the ecosystem services concept and its implications for their assessment and management. C. R. Biol. 334, 441-449. doi:10.1016/j.crvi.2010.11.007

Langbein, W., Iseri, K., 1995. Science in Your Watershed - General Introduction and 
Hydrologic Definitions, Methods and practices of the Geological Survey. United States Geological Survey, Washington.

Le Gall, O., Aquitain, C. d'Homologation, LPO, 2012. La liste des oiseaux d'Aquitaine (arrêtée au 31 juillet 2012).

Lebourgeois, F., Jabiol, B., 2006. Enracinements comparés du Chêne sessile, du Chêne pédonculé et du Hêtre. Réflexions sur l'autécologie des essences. Rev. For. Française. doi: $10.4267 / 2042 / 4898$

Leh, M.D.K., Matlock, M.D., Cummings, E.C., Nalley, L.L., 2013. Quantifying and mapping multiple ecosystem services change in West Africa. Agric. Ecosyst. Environ. 165, 6-18. doi:10.1016/j.agee.2012.12.001

Levrel, H., Bouamrane, M., 2008. Instrumental Learning and Sustainability Indicators: Outputs from Co-Construction Experiments in West African Biosphere Reserves. Ecol. Soc. 13, 28.

LPO Aquitaine, 2013. Faune d'Aquitaine, LPO (Ligue pour la Protection des Oiseaux). Maes, J., Egoh, B., Willemen, L., Liquete, C., Vihervaara, P., Schägner, J.P., Grizzetti, B., Drakou, E.G., Notte, A. La, Zulian, G., Bouraoui, F., Luisa Paracchini, M., Braat, L., Bidoglio, G., 2012. Mapping ecosystem services for policy support and decision making in the European Union. Ecosyst. Serv. 1, 31-39. doi:10.1016/j.ecoser.2012.06.004

Mann, L., Tolbert, V., Cushman, J., 2002. Potential environmental effects of corn (Zea mays L.) stover removal with emphasis on soil organic matter and erosion. Agric. Ecosyst. Environ. 89, 149-166. doi:10.1016/S0167-8809(01)00166-9

Matias, N.-G., Johnes, P.J., 2011. Catchment Phosphorous Losses: An Export Coefficient Modelling Approach with Scenario Analysis for Water Management. Water Resour. Manag. 26, 1041-1064. doi:10.1007/s11269-011-9946-3

McKenzie, E., Posner, S., Tillmann, P., Bernhardt, J.R., Howard, K., Rosenthal, A., 2014. Understanding the use of ecosystem service knowledge in decision making: lessons from international experiences of spatial planning. Environ. Plan. C Gov. Policy 32, 320-340. doi:10.1068/c12292j

MEA, 2005. Rapport de synthèse de l'Évaluation des Écosystèmes pour le Millénaire, Millennium Ecosystem Assessment. Island Press, Washington, DC.

Mollier, A., 1999. Croissance racinaire du maïs (Zea mays L.) sous déficience en phosphore. Etude expérimentale et modélisation. Université Paris-Sud, UFR scientifique d'Orsay, INRA Bordeaux.

Naeem, S., Bunker, D.E., Hector, A., Loreau, M., Perrings, C., 2009. Biodiversity, Ecosystem 
Functioning, and Human Wellbeing. Oxford University Press.

doi:10.1093/acprof:oso/9780199547951.001.0001

NASA, 2012. ASTER Global Digital Elevation Map.

Nelson, E., Mendoza, G., Regetz, J., Polasky, S., Tallis, H., Cameron, Dr., Chan, K.M.A., Daily, G.C., Goldstein, J., Kareiva, P.M., Lonsdorf, E., Naidoo, R., Ricketts, T.H., Shaw, Mr., 2009. Modeling multiple ecosystem services, biodiversity conservation, commodity production, and tradeoffs at landscape scales. Front. Ecol. Environ. 7, 4-11. doi:10.1890/080023

Niemelä, J., Saarela, S.-R., Söderman, T., Kopperoinen, L., Yli-Pelkonen, V., Väre, S., Kotze, D.J., 2010. Using the ecosystem services approach for better planning and conservation of urban green spaces: a Finland case study. Biodivers. Conserv. 19, 3225-3243. doi:10.1007/s10531-010-9888-8

Panagos, P., Van Liedekerke, M., Jones, A., Montanarella, L., 2012. European Soil Data Centre: Response to European policy support and public data requirements. Land use policy 29, 329-338. doi:10.1016/j.landusepol.2011.07.003

Payraudeau, S., Tournoud, M., Cernesson, F., Picot, B., 2002. Modélisation de la charge annuelle en azote et phosphore par analyse spatiale d'informations topographiques et d'occupation des sols - Cas d'un petit bassin versant méditerranéen. Rev. EAT thématique $27-35$.

Peh, K.S.-H., Balmford, A., Bradbury, R.B., Brown, C., Butchart, S.H.M., Hughes, F.M.R., Stattersfield, A., Thomas, D.H.L., Walpole, M., Bayliss, J., Gowing, D., Jones, J.P.G., Lewis, S.L., Mulligan, M., Pandeya, B., Stratford, C., Thompson, J.R., Turner, K., Vira, B., Willcock, S., Birch, J.C., 2013. TESSA: A toolkit for rapid assessment of ecosystem services at sites of biodiversity conservation importance. Ecosyst. Serv. 5, 51-57. doi:10.1016/j.ecoser.2013.06.003

Pereira, T.C., Seabra, T., Maciel, H., Torres, P., 2009. Portuguese National Inventory Report on Greenhouse Gases, 1990-2007 submitted under the United Nations Framework Convention on Climate Change and the Kyoto Protocol. Amadora Port. Environ. Agency.

Reckhow, K.H., Beaulac, M.N., Simpson, J.T., 1980. Modeling Phosphorus Loading and Lake Response Under Uncertainty: A Manual and Compilation of Export Coefficients. United States Environmental Protection Agency, Washin.

Renard, K.G., Freimund, J.R., 1994. Using monthly precipitation data to estimate the R-factor in the revised USLE. J. Hydrol. 157, 287-306. doi:10.1016/0022-1694(94)90110-4 
Rosenthal, A., Verutes, G., McKenzie, E., Arkema, K.K., Bhagabati, N., Bremer, L.L., Olwero, N., Vogl, A.L., 2015. Process matters: a framework for conducting decisionrelevant assessments of ecosystem services. Int. J. Biodivers. Sci. Ecosyst. Serv. Manag. 11, 190-204. doi:10.1080/21513732.2014.966149

Rouse, J.W., Haas, R.H., Schell, J.A., Deering, D.W., 1974. Monitoring vegetation systems in the Great Plains with ERTS, in: 3rd Earth Resource Technology Satellite (ERTS) Symposium. NASA. Goddard Space Flight Center, pp. 309-317.

Ruckelshaus, M., McKenzie, E., Tallis, H., Guerry, A., Daily, G., Kareiva, P., Polasky, S., Ricketts, T., Bhagabati, N., Wood, S.A., Bernhardt, J., 2015. Notes from the field: Lessons learned from using ecosystem service approaches to inform real-world decisions. Ecol. Econ. 115, 11-21. doi:10.1016/j.ecolecon.2013.07.009

Ruiz-Labourdette, D., Schmitz, M.F., Montes, C., Pineda, F.D., 2010. Zoning a Protected Area: Proposal Based on a Multi-thematic Approach and Final Decision. Environ. Model. Assess. 15, 531-547. doi:10.1007/s10666-010-9223-5

Ruys, R., Couzi, L., Bernard, Y., 2012. La liste des mammifères terrestres d'Aquitaine (arrêtée au 30 septembre 2012).

Tallis, H., Kareiva, P., 2006. Shaping global environmental decisions using socio-ecological models. Trends Ecol. Evol. 21, 562-568. doi:10.1016/j.tree.2006.07.009

Tallis, H., Polasky, S., 2011. Assessing multiple ecosystem services: an integrated tool for the real world, in: Natural Capital. Oxford University Press, pp. 34-50. doi:10.1093/acprof:oso/9780199588992.003.0003

Tallis, H., Polasky, S., 2009. Mapping and Valuing Ecosystem Services as an Approach for Conservation and Natural-Resource Management. Ann. N. Y. Acad. Sci. 1162, 265-283. doi:10.1111/j.1749-6632.2009.04152.x

Tallis, H., Rickets, T., Guerry, A., Wood, S., Sharp, R., Nelson, E., Ennaanay, D., Wolny, S., Olwero, E., Vigerstol, K., Pennington, D., Mendoza, G., Aukema, J., Foster, J., Forrest, J., Cameron, D., Arkema, K., Lons, E., Kennedy, C., Verutes, G., Kim, C.K., Guannel, G., Papenfus, M., Toft, J., Marsik, M., Bernhardt, J., Griffin, R., 2014. InVEST 3.0.1 User's Guide: Integrated Valuation of Environmental Services and Tradeoffs.

Trabucco, A., Zomer, R.J., 2009. Global Aridity Index (Global-Aridity) and Global Potential Evapo-Transpiration (Global-PET) Geospatial Database.

Watson, D.J., 1947. Comparative Physiological Studies on the Growth of Field Crops: I. Variation in Net Assimilation Rate and Leaf Area between Species and Varieties, and within and between Years. Ann. Bot. 41-76 SE - 11(1). 
Wischmeier, S., 1978. Predicting rainfall erosion losses: A guide to conservation planning. U.S. Department of Agriculture, Washington, DC.

Wochna, A., Lange, K., Urbanski, J., n.d. Wochna A., Lange K. and Urbanski J., 2011. The influence of land cover change during sixty years on non-point source phosphorus loads to Gulf of Gdansk. J. Coast. Res.

WRI, 2012. The Corporate Ecosystem Services Review: Guidelines for Identifying Business Risks and Opportunities Arising from Ecosystem Change. World Resources Institute, Washington, DC. 